International Journal of Business Economics (IJBE)

Vol, 2 Issue 2, pp 99-112, March - August 2021

http://jurnal.umsu.ac.id/index.php/ijbe

eISSN 2686-472X

ORIGINAL ARTICLE

\title{
Influence Current Ratio, Debt to Equity Ratio and Total Asset Turnoveron Return on Equity in the Transportation Sector Industry
}

\author{
Qahfi Romula Siregar ${ }^{*}$, Defi Desvita Harahap ${ }^{1}$
}

\begin{abstract}
His study aims to determine whether there is an effect of Current Ratio, Debt To Equity Ratio, and Total Assets Turnover on Return On Equity in transportation sector companies listed on the Indonesia Stock Exchange. The approach used is an associative approach. The population in this study are retail trade sector companies listed on the Indonesia Stock Exchange for the 2015-2019 period. Samples were taken using purposive sampling method in order to obtain 7 companies as samples. And using multiple linear regression analysis methods, classical assumption test, $t$ test (partial test), $\mathrm{f}$ test (simultaneous test) and coefficient of determination with the help of software SPSS V.20 (Statistical Product and Service Solutions). Based on the research results, it can be concluded that partially Total Assets Turnover has a significant effect on Return On Equity, while Current Ratio, Debt To Equity Ratio have no and insignificant effect on Return On Equity. And simultaneously Current Ratio, Debt To Equity Ratio, and Total Assets Turnover have a significant effect on Return On Equity in Transportation sector companies listed on the Indonesia Stock Exchange for the period 2015-2019.
\end{abstract}

Keywords: Current Ratio, Debt To Equity Ratio, Total Assets Turnover, Return On Equity

DOI : https://doi.org/10.30596/ijbe.v2i2.6644

JEL Classification: O15, L84, L25, J21

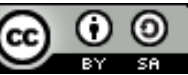

Published byInternational Journal of Business Economics (IJBE), Indonesia | Copyright $\odot 2021$ by the Author(s) | This is an open access article distributed under the Creative Commons Attribution

License http://creativecommons.org/licenses/by/4.0), which permitsunrestricted use, distribution, and reproduction in any medium, provided the original work is properly cited.

Cite this article as:

Siregar, Q. R., \&Harahap, D. D., (2021).Influence Current Ratio, Debt to Equity Ratioand Total Asset Turnoveron Return on Equity in the Transportation Sector Industry. International Journal of Business Economics (IJBE), 2(2), 99-112.

Faculty of Economic and Business, Universitas Muhammadiyah Sumatera Utara Jln. Kapten Muchtar Basri No. 3 Medan 20238, Indonesia

*Corresponding Author: qahfiromula@umsu.ac.id 


\section{International Journal of Business Economics (IJBE)}

Vol, 2 Issue 2, pp 99-112, March - August 2021

http:/ /jurnal.umsu.ac.id/index.php/ijbe

eISSN 2686-472X

\section{INTRODUCTION}

In this modern era, many companies were founded with the aim of increasing the value of the company so that it can provide prosperity for the owners or shareholders and the company. Competition in industry requires each company to develop its business by improving management performance, especially the company's financial performance. Therefore, if a company wants to always appear to have good management skills, the company must be able to carry out good financial management. Every company needs funds, either for starting up or developing a business that is already in progress. Funds are very important in supporting company continuity. Therefore, the need for a company for funds will never end so that in some cases, owing money becomes one of the ways that must be taken. Actually owing is fine as long as you also apply profitability. In running its business, companies must be involved in what is called debt. Debt is an obligation that must be paid by a company to another party within the promised time as a result of transactions that have occurred in the past. The amount of company debt is closely related to profitability. profitability is the ratio to assess the company's ability to seek profit. Meanwhile, the solvency ratio is the ratiobetween the amount of assets owned by the company and the debts that must be borne. From this solvency ratio, we can find out the extent to which the company is able to pay off its debts if the company is liquidated.

"Return On Equity namely the ratio between profit after tax to total own capital from paid-in owner'scapital Return On Equity shows that the company is more efficient in managing its own capital to generate profit / net profit "(Jufrizen \& Sari, 2019).

The factors that affect the profitability ratio are: Profit Margin: there are four factors that increase the company's ability to generate funds internally and will increase the company's continued growth. Dividend policy: The lower the percentage of net income paid as dividends, the higher the retained earnings ratio. This increases the company's own capital from within and will enhance the company's sustainable growth.

According to (Prihadi, 2019, p. 209) Current Ratio is the ratio to measure how far the company's current assets are able to pay off its short-term liabilities. Assets have potential use one year from the date of the financial statements. Current debt also determines the maximum payment for one year from the balance sheet date.

Influencing factors Current Ratio are as follows: Distribution of items from current assets. Trend data from current assets and short-term debt for a period of 5 or 10 years, the terms of credit given by creditors to companies in returning goods, and terms of credit given by companies to customers in selling goods. Present value or market value or exchange value of merchandise and rate of collection of accounts receivable. Possible changes in the value of current assets. Changes in inventory in relation to current and future sales volume.

According to (Kasmir, 2018, p. 157) states that Debt To Equity Ratio ( DER) is the ratio used to value debt to equity. This ratio is sought by comparing all debt, including current debt, and total equity.

influencing factors Debt to Equity Ratio are as follows: Sales Level Companies with relatively stable sales means that they have relatively stable cash flow, so they can use larger debt than companies with unstable sales. Company Growth Rate Company growth rate is the company's ability to produce size. Profitability The company's ability to generate profits and a measure in percentage used to assess the extent to which the company is able to generate profits at an acceptable level. 


\section{International Journal of Business Economics (IJBE)}

Vol, 2 Issue 2, pp 99-112, March - August 2021

http:/ /jurnal.umsu.ac.id/index.php/ijbe

eISSN 2686-472X

According to (Fahmi, 2017, p. 135) stated Total Assets Turnover also called the total asset turnover.This ratio looks at the extent to which all assets owned by the company turn over effectively.high low factor Total Assets Turnover determined by: By increasing business capital (operating assetsturnover) Attempting to achieve a certain level, increase sales as much as possible. By reducing sales to acertain level, efforts will be made to reduce or reduce operating assets as much as possible. Total AssetTurnover shows the asset's turnover in terms of sales volume in other words how far all assets are able tocreate sales. The higher the ratio Total Asset Turnover means the better, because of the effective use of assets in generating sales, so it can be said that the resulting profit is also high and thus the financial performance is getting better.

According to (Kasmir, 2018, p. 204) states that Return On Equity ( ROE) is a ratio to measure net profit after tax with own capital. The higher this ratio, the better. This means that the position of the company owner is getting stronger, and vice versa.

According to (Fahmi, 2017, p. 137) states that Return On Equity ( ROE) is also known as the return on equity. From several references it is also called the ratio of total asset turnover or total asset turnover. This ratio examines the extent to which a company uses its resources to be able to provide a return on equity.

"Return On Equity that is, the ratio between profit after tax to own capital from paid-up capital of thebusiness owner. The higher it is Return On Equity shows the more efficient companies are in managing their own capital to generate profit or net profit "(Jufrizen \& Sari, 2019).

In measuring the company's performance in obtaining profits that are available to shareholders in the company or to find out whether the size of the company is large or small, it is affected by the company's debt. If the company's debt is getting bigger, then this ratio will be even bigger. This ratio can be calculated using the formula:

Return On Equity $(\mathrm{ROE})=$ Net income after tax

Total Equity

Current Ratio ( CR) is included in the liquidity ratio. Liquidity ratio is the ability of a company to meet itsshort-term obligations in a timely manner. Liquidity, often referred to as the working capital ratio, is the ratio used to measure how liquid a company is.

According to (Kasmir, 2018, p. 134) states that: Current Ratio is the ratio to measure the company's ability to pay short-term obligations or debt that is due immediately when collected in full or debt that is due immediately when collected in its entirety. How many current assets are available to cover short-term liabilities that are due soon. Current ratio can also be said as a form to measure the level of security of a company.

According to (Fahmi, 2017, p. 121) states that: " Current Ratio is a measure commonly used for short-term solvency, the ability of a company to meet its debt needs when it matures. It must be understood that the use of current ratios in analyzing financial statements is only able to provide broad analysis, therefore it is necessary to support a more comprehensive qualitative analysis ".

"Current ratio ( current ratio) is the best indicator of the extent to which claims from short-term creditors have been covered by assets that are expected to be converted into 


\section{International Journal of Business Economics (IJBE)}

Vol, 2 Issue 2, pp 99-112, March - August 2021

http:/ /jurnal.umsu.ac.id/index.php/ijbe

eISSN 2686-472X

cash fairly quickly, this ratio is the most frequently used measure of short-term solvency "(Argananta \& Hidayat, 2017).

Can be concluded that Current Ratio is a ratio that aims to measure the ability of a company to meet short-term obligations or total debt that is due immediately when collected as a whole in accordance with the provisions of the company. formula to find Current Ratio which can be used as follows:

Current Ratio $(\mathrm{CR}))=\underline{\text { Current Assets }}$

Current Liabilities

(2)

According to (Ekananda, 2019, p. 460) states Debt to Equity Ratio ( DER) Directly will measure the degree of a company's capital, as well as to determine the level of the company's ability to meet its obligations to pay debts, both long-term debt and short-term debt.

According to (Kasmir, 2018, p. 157) states that Debt to Equity Ratio ( DER) is a rasui that is used to value debt with equity. This ratio is sought by comparing all debt, including current debt, and total equity.

According to (Fahmi, 2017, p. 127) states that it will measure the degree of debt to equity ratio ( Debt toEquity Ratio) It will directly measure the degree of a company's capital, as well as to determine the level ofthe company's ability to meet its obligations to pay debt, both long-term debt and short-term debt.

Can be concluded that Debt to Equity Ratio is a ratio that can be used to calculate and assess debt to equity from each amount that is used as collateral for the total debt. This ratio can be used to measure the company in compliance all short-term and longterm liabilities of the company. formula used to measure Debt to Equity Ratio are as follows:

Debt To Equity Ratio $($ DER $)=\frac{\text { Total Debt }}{\text { Total Equity }}$

The activity ratio is the ratio used to measure the effectiveness of the company in using the activities of the company in using its assets. The use of the activity ratio is by comparing the level of sales with investment in assets for one period .

According to (Sudana, 2015, p. 25) states that Total Assets Turnover is a ratio measuring the effectiveness of the use of all assets in generating sales, and if the greater this ratio means the more effective the management of all assets owned by the company. Meanwhile, according to (Kasmir, 2018, total asset turnover is a ratio used to measure the turnover of all assets owned by the company and measure the amount of sales earned from each rupiah of assets.

"Total Asset Turnover is a financial ratio that measures the efficiency of the company's use of itsassets in generating sales revenue or sales revenue to the company, Total Assets Turnover is a comparison between net sales or net sales with total assets, namely the accumulation of fixed assets and current assets "(Wahyuni, 2017).

Can be concluded Total Asset Turnover is a ratio that measures the effectiveness of the use of all assets in generating sales. The use of the activity ratio is to compare the 


\section{International Journal of Business Economics (IJBE)}

Vol, 2 Issue 2, pp 99-112, March - August 2021

http:/ /jurnal.umsu.ac.id/index.php/ijbe

eISSN 2686-472X

level of sales with investment in assets for one period. The formula used to measure total asset turnover is as follows:

TotalAsset Turnover $($ TATo $)=$ Sales

Total Assets .

Current Ratio is the ratio most commonly used to analyze the working capital position of a company.The higher this ratio, the guaranteed debt - the company's debt to creditors. This ratio is used to measure the ability of a company to pay short-term liabilities by using its current assets. Based on the results of research conducted partially, the CR variable does not have a significant effect on ROE (Pratomo, 2017).Current Ratio has a significant effect on Return On Equity ( Alpi, 2018) Current Ratio significant effect on Return On Equity ( Yusnandar, 2019). Meanwhile, based on researchaccording to (Hasibuan, 2018) concluded that Current Ratioeffect on Return On Equity.

Because Current Ratio is a ratio to measurethe company's ability to pay off its short-term debt. Then according to (Son, 2020) states that partially Current Ratio has no significant effect on Return On Equity, This is because the increased profit will have an effectReturn On Equity. Based on the research above, it can be concluded that the variables

Current Ratio has a significant effect on the dependent variable Return On Equity. Return On Equity whichtends to indicate the company indicates the company has dependents that must be resolved.

Debt To Equity Ratio ( DER) is a financial ratio that compares total debt to equity. Equity and theamount of debt used for the company's operations must be proportional. Debt to Equity Ratio ( DER) is also known as the leverage ratio or leverage ratio. Leveraging ratio is the ratio used to measure an investment in a company. Partially the DER variable does not have a significant effectagainst ROE (Destari\& Hendratno, 2019).

Meanwhile, according to (Sipahutar\& Gultom, 2017) concluded that Debtto Equity Ratio have an influence on Return Onor significant.Variable Debt to Equity Ratio significant effect on Return On Equity in research (Jufrizen \& Sari,2019). Then Debt to Equity Ratio significant effect on Retrun On Equity (Wahyuni, 2017).Debt to Equity Ratio negative and insignificant effect on Return On Equity ( Juandi, Djamereng, \& Budiandriani,2019).

Meanwhile, according to (Hasibuan, 2018) Debt to Equity effect on Return On Equity. It can be concluded that, a high solvency ratio will result in a decrease in profitability.Based on the research above, it can be concluded that the insight is variable Debt To Equity Ratio has a significant effect on the dependent variable Return On Equity(ROE). This explains that Debt to Equity Ratio which tends to explain that the company has a responsibility on a third party in completing its obligations.

Total asset turnover is one of the activity ratios used to determine the effectiveness of a company in managing its business. The company's operating activities require investment, both for short-term assets (Inventory and Account Receivable) and long-term (Property Plans, and Equipment). This ratio illustrates the relationship between the level of the company's sales operation and the company's assets needed to support the company's operations. 


\section{International Journal of Business Economics (IJBE)}

Vol, 2 Issue 2, pp 99-112, March - August 2021

http:/ /jurnal.umsu.ac.id/index.php/ijbe

eISSN 2686-472X

Total Asset Turnover measures how efficiently a company uses assets to obtain company sales(Wahyuni, 2017). Based on the results of research conducted that Total Asset Turnover significant effect on ReturnOn Equity ( Jufrizen\& Sari, 2019).

Based on the results of research conducted partially, it shows that partially working capital turnover has no significant effect on return on equity (Jessica, Lilia, Leonardy, Kartika, \& Panggabean, 2020).

Meanwhile, according to (Jufrizen, 2015) it can be concluded that Total Asset Turnover HO is rejected and Ha is accepted, that is Total Asset Turnoversignificant effect on Return On Equity. Then the above research canit can be concluded that it is variable Total Asset Turnover has no significant effect on the dependent variable ReturnOn Equity (ROE). This is due to Net Profit Margin does not represent all components of the company inachieving net income.

Based on the results of the research conducted, it shows that there is a significant effect simultaneously between DER, CR, TATO, on ROE. And partially, they have a significant negative effect on ROE, while DER, CR, and TATO have no effect on ROE (Destari \& Hendratno, 2019).

Based on the results of research carried out, the results of this study indicate that the variables CR, DER, and TATO simultaneously influence ROE (Argananta \& Hidayat,2017). Meanwhile, according to research (Wahyuni, 2017) concludes that partially

Current Ratio, Debt to Equity Ratio, except Total Asset Turnover. Simultaneously Current Ratio, Debtto Equity Ratio, Total Asset Turnover and Inventory significantly influence Return On Equity.

Current Ratio, Debt To Equity Ratio, Total Asset Turnover significant effect on Return on Equity (Wahyuni, 2017). From the explanation above it can be concluded that the variableCurrent Ratio, Debt To Equity Ratio and Total Asset Turnover has a significant effect on Return On Equity.

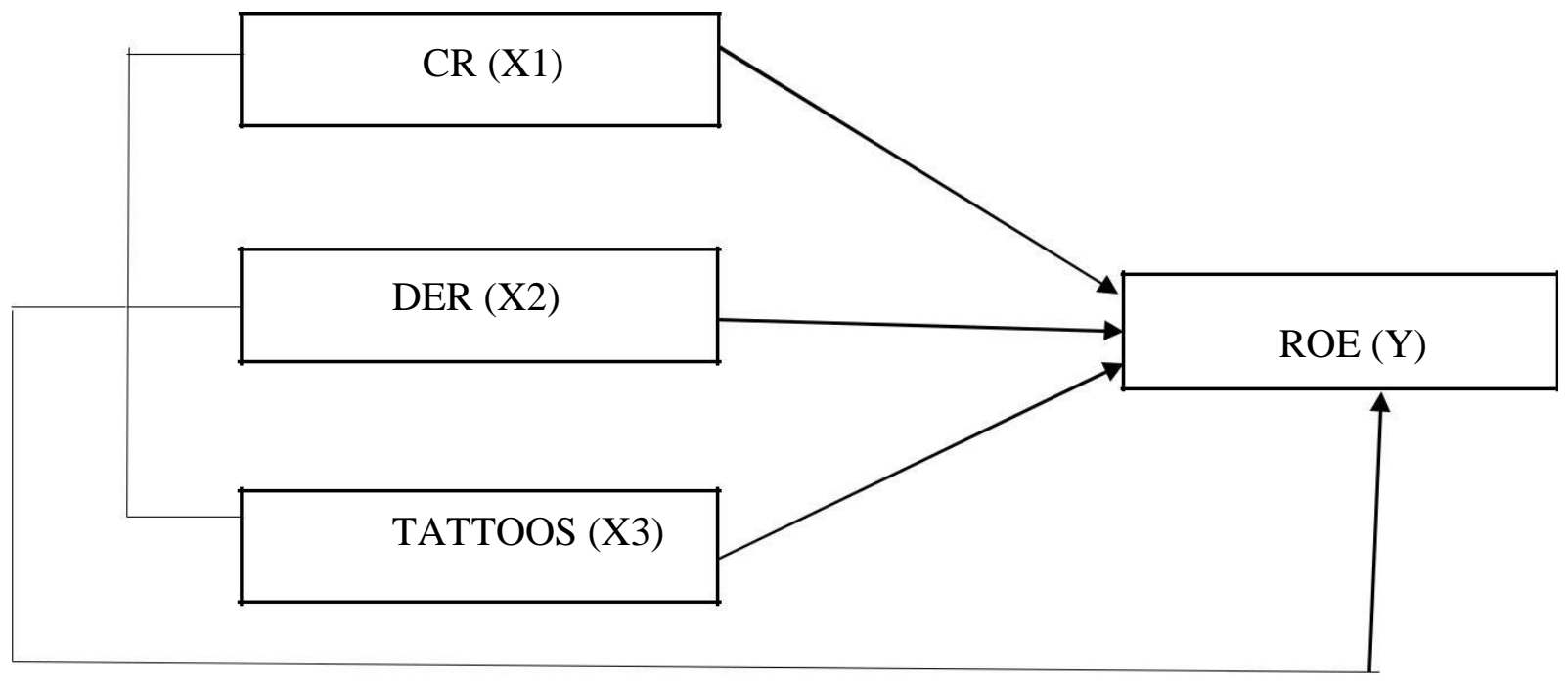

Figure 1. Research Paradigm

\section{METHOD}

The research approach used in this research is an associative approach. The type of data used is quantitative, namely in the form of numbers (Secondary Data) by using a ratio 


\section{International Journal of Business Economics (IJBE)}

Vol, 2 Issue 2, pp 99-112, March - August 2021

http://jurnal.umsu.ac.id/index.php/ijbe

eISSN 2686-472X

scale based on a formula that is used as the basis for measurement and using a statistical analysis tool in the form of Path Analysis. The population in this study were all companies in the transportation sector listed on the Indonesia Stock Exchange as many as 46 companies. The sample selection procedure is carried out by technique purposive sampling.

The samples in this study were 7 companies. Secondary data from this study were obtained from the publication of corporate financial reports listed on the Indonesia Stock Exchange. Data processing using SPSS software version 20, the statistical analysis of the instruments in this research includes: calcic assumption test, normality test, multicolinearity test, hetercodesticity test, and autocorrelation test.

\section{RESULTS AND DISCUSSION} Results

The normality test is used to test whether the regression model between the independent variable and the dependent variable has a normal distribution, this can be seen by testing the P-plot graph, the VIF value and scatterplot

\section{Normal P-P Plot of Regression Standardized Residual}

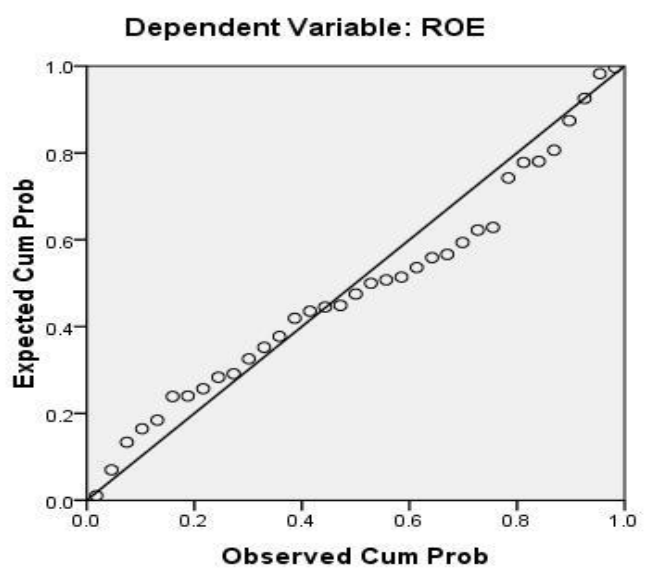

Figure 2. Data Normality P-Plot Results

Based on the picture above, it can be seen that the results of the data normality test show that the distribution of data points tends to approach the diagonal line or the histogram graph. Shows a normal distribution pattern, then the regression model fulfills the normality assumption. This means that the regression method is normally distributed and worthy of analysis.

Table 1. Multicolinearity Test

\begin{tabular}{lrl}
\hline Model & \multicolumn{3}{c}{ Collinearity Statistics } \\
\cline { 2 - 3 } & Tolerance & VIF \\
\hline (Constant) & .595 & 1.679 \\
CR & .588 & 1.699 \\
DER & .984 & 1.016 \\
TATO & & \\
\hline
\end{tabular}




\section{International Journal of Business Economics (IJBE)}

Vol, 2 Issue 2, pp 99-112, March - August 2021

http://jurnal.umsu.ac.id/index.php/ijbe

eISSN 2686-472X

From the data in the table above, it can be seen that there is no multicollinearity symptom between the independent variables as indicated by the value tolerance each independent variable is greater than 0.1 and the BIF value is less than 10 . So it can be concluded that further analysis can be carried out using multiple regression models

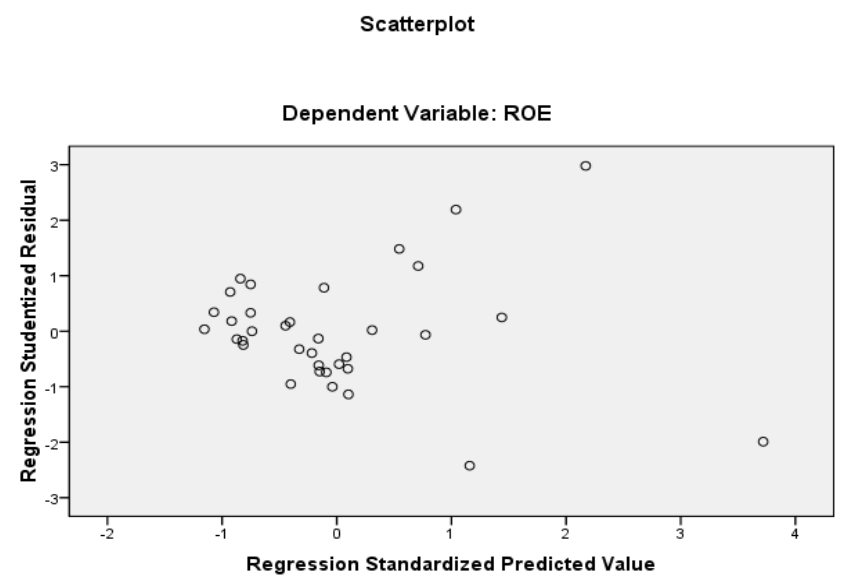

Figure 2. Scatterplot of Heteroscedasticity Test

In the form of the image above we can see that the dots spread randomly, and do not form a certain pattern or line that is regular either at the top of the zero or at the bottom of the zero from the vertical axis or on the $\mathrm{Y}$ axis. on the regression model.

Table 2. Multiple Linear Regression

\begin{tabular}{|c|c|c|c|c|c|c|}
\hline \multirow[b]{2}{*}{ Model } & & \multicolumn{2}{|c|}{ Unstandardized Coefficients } & $\begin{array}{l}\text { Standardized } \\
\text { Coefficients }\end{array}$ & \multirow[b]{2}{*}{$\mathrm{T}$} & \multirow[b]{2}{*}{ Sig. } \\
\hline & & B & Std. Error & Beta & & \\
\hline \multirow[t]{4}{*}{1} & (Constant) & .038 & .063 & & 612 & .545 \\
\hline & CR & -7.246 & .000 & -.084 & -.514 & .611 \\
\hline & DER & .000 & .000 & -.192 & -1.160 & .255 \\
\hline & TATO & .235 & .042 & .711 & 5.568 & .000 \\
\hline
\end{tabular}

Based on table 4.9 above, the multiple linear regression equation that can be formulated is as follows: $\mathrm{Y}=0.038+-7,246+0,000+0.235$. With the intrepretation the value of $\mathrm{a}=0.338$ indicates that if the independent variable is Current Ratio ( X 1), Debt To Equity Ratio ( X2)and Total Asset Turnover ( TATTOOS) is in a constant state or does not change(equal to zero), then the value Return On Equity ( $Y$ ) is equal to 0.038. The regression coefficient value $\mathrm{X} 1=-7,246$ means that the other independent variables are fixed and Current Ratio increased by $1 \%$ then Return On Equity ( Y) will decrease by 7,246. The coefficient is negative, meaning that there is a negative relationship between Current Rato withReturn On Equity ( stock price). Getting up Return On Equity the lower the share price. The regression coefficient value $\mathrm{X} 2=0,000$ means that if other independent variables the value is fixed and Debt To Equity Ratio experience 1\% then the share price $(\mathrm{Y})$ will decrease by 0.000 . The coefficient is positive,meaning that there is a positive relationship between Return On Equity ( stock price). Getting up Debt To 


\section{International Journal of Business Economics (IJBE)}

Vol, 2 Issue 2, pp 99-112, March - August 2021

http:/ /jurnal.umsu.ac.id/index.php/ijbe

eISSN 2686-472X

EquityRatio hence the stock increases. The regression coefficient value $\mathrm{X} 3=0.235$ means that if other independent variables the value is fixed and Total Asset Turnover experience $1 \%$ then the stock price (Y) will decrease by 0.235 . The coefficient ispositive, meaning that there is a positive relationship between Return On Equity ( stock price). Getting up TotalAsset Turnover hence the stock increases.

\section{T test (Partially)}

The purpose of the $t$ test is to see whether there is a significant relationship or not in the relationship between variable X 1 X 2 and $X 3$ against $Y 1$

Table 3. $t$ test results

\begin{tabular}{|c|c|c|c|c|c|c|}
\hline \multirow[b]{2}{*}{ Mode } & & \multicolumn{2}{|c|}{ Unstandardized Coefficients } & \multirow{2}{*}{$\begin{array}{c}\text { Standardized } \\
\text { Coefficients }\end{array}$} & \multirow[b]{2}{*}{$\mathrm{T}$} & \multirow[b]{2}{*}{ Sig. } \\
\hline & & B & Std. Error & & & \\
\hline \multirow[t]{4}{*}{1} & (Constant) & .038 & .063 & & 612 & .545 \\
\hline & $\mathrm{CR}$ & -7.246 & .000 & -.084 & -.514 & .611 \\
\hline & DER & .000 & .000 & -.192 & -1.160 & .255 \\
\hline & TATO & .235 & .042 & .711 & 5.568 & .000 \\
\hline
\end{tabular}

Influence Current Ratio (CR) against Return On Equity (ROE)

Based on the partial test results between Current Ratio (CR) against Return On Equity (ROE) obtained $t_{\text {countis }}-0.514$ and $t_{\text {table }}$ with $\alpha=5 \%$, it is known that it is 2.034 with a significant level of- $0.514<2.034$. From these results it can be concluded that $\mathrm{H}_{\mathrm{o}}$ rejected and $\mathrm{H}_{\mathrm{a}}$ accepted, this indicates that there is no intermediate but not significant effect Current Ratio (CR) against Return On Equity (ROE) in Transportation Sector companies listed on the Indonesian Stock Exchange.

\section{Influence Debt To Equity Ratio (DER) against Return On Equity ( ROE)}

Based on the partial test results between Debt To Equity Ratio (DER) against Return On Equity (ROE) obtained $t_{\text {countis }} 0.000$ and $t_{\text {table }}$ where $\alpha=5 \%$ is known as 2.034 with a significant level of $-0.192>2.034$. From these results it can be concluded that $\mathrm{H}_{\mathrm{o}}$ accepted and $\mathrm{H}_{\mathrm{a}}$ rejected, this indicates that there is no significant effect between. Debt To Equity Ratio to Return On Equity (ROE) in Transportation Sector Companies listed on the Indonesia Stock Exchange

\section{Influence Total Assets Turnover (TATO) against Return On Equity ( ROE)}

Based on the partial test results between Total Assets Turnover (TATO) againstReturn On Equity (ROE) obtained $t_{\text {countis }} 0.235$ and $t_{\text {table }}$ where $\alpha=5 \%$ is known as2,034 with a significant level of 5,568>2,034. From these results it can be concluded that $\mathrm{H}_{\mathrm{o}}$ accepted and $\mathrm{H}_{\mathrm{a}}$ rejected, this shows that there is a significant influence between Total Assets Turnover (TATO) to ReturnOn Equity ( ROE) in Transportation Sector Companies listed on the Indonesia Stock Exchange.

\section{F test (Simultaneously)}

The F statistical test (simultaneous) was conducted to determine whether the independent variable was (independent) together have a significant or no effect on the dependent variable. Simultaneous test results can be seen in the table below: 


\section{International Journal of Business Economics (IJBE)}

Vol, 2 Issue 2, pp 99-112, March - August 2021

http://jurnal.umsu.ac.id/index.php/ijbe

eISSN 2686-472X

Table 4. F Test Results

\begin{tabular}{|c|c|c|c|c|c|c|}
\hline \multicolumn{2}{|c|}{ Model } & Sum of Squares & Df & Mean Square & \multirow{2}{*}{$\frac{F}{10.431}$} & \multirow{2}{*}{$\frac{\text { Sig. }}{.000^{\mathrm{a}}}$} \\
\hline 1 & Regression & .449 & 3 & .150 & & \\
\hline & Residual & .445 & 31 & .014 & & \\
\hline & Total & .894 & 34 & & & \\
\hline
\end{tabular}

a. Predictors: (Constant), TATO, CR, DER

b. Dependent Variable: ROE

From the results of data processing above, It can be seen that $F_{\text {count }} 10,431>$ from $\mathrm{F}_{\text {table }}=2.91$ (seetable $\mathrm{F}$ for $\mathrm{N}=31$ ) with a probability value that is sig is equal to 0.000 $<0.05$. This means that the results above indicate that there is a significant effect simultaneously Current Ratio (CR),Debt To Equity Ratio (DER) and Total Asset Turnover to Return On Equity ( ROE) in Transportation Sector companieslisted on the Indonesia Stock Exchange for the period 2015 - 2019.

\section{The Coefficient of Determination $\left(\mathbf{R}^{2}\right)$}

The coefficient of determination is used to determine how much influence the independent variables have on the dependent variable. The value of the efficiency of determination is determined by value $\mathrm{R}$ square.

Table 5. Coefficient of Determination

\begin{tabular}{|c|c|c|c|c|}
\hline Model & $\mathrm{R}$ & R Square & $\begin{array}{c}\text { Adjusted R } \\
\text { Square }\end{array}$ & Std. Error of the Estimate \\
\hline 1 & $.709^{\mathrm{a}}$ & .502 & .454 & ,11979381 \\
\hline
\end{tabular}

a. Predictors: (Constant), TATO, CR, DER

b. Dependent Variable: ROE

b. Dependent Variable: ROE

From the table above it can be shown that the value of R-Square $\left(\mathrm{R}^{2}\right)$ of 0.502 or $5.2 \%$, which means that the percentage of the influence of the independent variable (Current Ratio, Debt To Asset Ratio and Total AssetTurnover) to the dependent variable (Return On Equity) is 5.2\% while the rest $94.8 \%$ is influenced by other factorsnot included in this study.

\section{Discussion}

\section{Influence Current Ratio (CR) against Return On Equity (ROE)}

Based on the research results obtained regarding the influence Current Ratio (CR) against Return On Equity (ROE) in transportation companies listed on the Stock ExchangeIndonesia. The result of hypothesis test partially shows that the value of $t_{\text {count }}$ for variables Current Ratio is -0.514 and $t_{\text {table }}$ with $\alpha=5 \%$ is known to be 2.034 thus $-t_{\text {count }}$ greater than $t_{\text {table }}(-0.514<2.034)$ and $\mathrm{H}_{\mathrm{o}}$ rejected and $\mathrm{H}_{\mathrm{a}}$ be accepted. Based on these results, it shows that partially there is an effect but not significant between Current Ratio to Return On Equity transportation companies listed on the Indonesia Stock Exchange for the period 2015-2019. This is due to the elements Current Ratio it self, where investors will usually pay more attention to the total debt the company has. The higher thevalue Current 


\section{International Journal of Business Economics (IJBE)}

Vol, 2 Issue 2, pp 99-112, March - August 2021

http:/ /jurnal.umsu.ac.id/index.php/ijbe

eISSN 2686-472X

Ratio it will make it difficult for the company to get additional loans from investors, because investors are afraid that the company will not be able to pay its obligations. Current Ratio not significant effect on Return On Equity shows that investors are paying more attention Cureent Ratio as a risk that can be considered in their investment decisions.

Current ratio or (Current Ratio) is a ratio to measure the company's ability to pay short-term obligations or debt that is due immediately when collected as a whole. In other words, how many current assets are available to cover short-term liabilities that are due soon. Current ratio can also be said as a form of measuring the level of security (margin of safety) a company. Calculation of the current ratio is done by comparing total current assets with total current debt.

The results of this study are in line with the results of research conducted by (Pratomo, 2017) and (Putra, 2020) which state that Current Ratio has no significant effect on Return On Equity. But this research is not in line with the results of research (Alpi, 2018), (Yusnandar, 2019) and (Syarifuddin, 2018), which state that Current Ratio significant effect on Return On Equity.

Therefore, the results of research conducted by researchers as well as the theory, as well as the opinionspresented above, are about the influence Current Ratio to Return On Equity then the authors conclude that there is aconformity between the results of the researchers and the theory. So, the authors conclude that the effect Current Ratio to Return On Equity is not a significant effect on the Transportation Sector which is listed on the Indonesia Stock Exchange for theperiod 2015-2019.

\section{Influence Debt To Equity Ratio (DER) against Return On Equity (ROE)}

Based on the research results obtained regarding the influence Debt To Equity Ratio(DER) against Return On Equity (ROE) in automotive companies listed on the Indonesia Stock Exchange. The result of hypothesis test partially shows that the value of $t$ count for variables Debt To Equity Ratio (DER) is -0.192 and t table where $\alpha=5 \%$ is known to be 2.034. Thus $-t_{\text {count }}$ smaller than $t_{\text {table }}(-0.192>2.034)$ and a significant value of 0.255 (greater than 0.05) means that $\mathrm{H}_{\mathrm{o}}$ accepted and $\mathrm{H}_{\mathrm{a}}$ rejected. Based on these results, it shows that partially there is no and not significant effect Debt To Equity Ratio(DER) against Return On Equity (ROE) in transportation companies listed on the Indonesia Stock Exchange for the period 2015-2019. This is because the company has heavy debts high, indicating that the company has a responsibility to a third party to complete its obligations. On the other hand, the high use of debt indicates that the company needs additional funds to increase its business to get more profit. However, investors are not interested in companies that have high debt levels because they have the potential to generate high risk as well.

Debt To Equity Ratio ( DER) is a ratio that compares total debt to total assets. The higher the value Debt To Equity Ratio ( DER) shows the large number of assets financed by debt, making it difficult for the companyto obtain additional loans from creditors because it is feared that the company will not be able to pay off its debts. Conversely, the lower the value Debt To Equity Ratio ( DER), the better the company's image in the eyes of creditors because the total assets owned by the company are financed by its own capital and the company will be able to easily make loans to creditors.

The results of this study are in line with the results of research conducted by (Destari \& Hendratno, 2019) and (Juandi et al., 2019) which state that Debt To Asset Ratio has no significant effect on Return OnEquity. But this research is not in line with 


\section{International Journal of Business Economics (IJBE)}

Vol, 2 Issue 2, pp 99-112, March - August 2021

http:/ /jurnal.umsu.ac.id/index.php/ijbe

eISSN 2686-472X

the results of research (Sipahutar \& Gultom, 2017), (Jufrizen \& Sari,2019), (Wahyuni \& Muslih, 2017) and (Syarifuddin, 2018) which states that Debt To Equity Ratio significant effect on Return On Equity.

The refore the results of the research conducted by the research as well as the theory as well as the income presented above are about influence Debt To Equity Ratio to Return On Equity. So the writer can conclude that thereis an agreement between the results of the research with the theory. So the writer can conclude that the Debt To Equity Ratio to Return On Equity has no significant effect on Transportation sector listed on the Indonesia StockExchange for the period 2015-2019.

\section{Influence Total Assets Turnover (TATO) against Return On Equity (ROE)}

Based on the research results obtained regarding the effect of Influence Total Asset Turnover (TATO) against Return On Equity (ROE) at a transportation company listed on the Indonesia Stock Exchange. The result of hypothesis test partially shows that the value of $t$ count for variables Total Asset Turnover ( TATO) is 5,568 and t table where $\alpha=5 \%$ is known as 2,034 . Thus $-t_{\text {count }}$ smaller than $t_{\text {table }}(5,568>2,034)$ and a significant value of0.000 (less than 0.05) means $\mathrm{H}_{\mathrm{o}}$ accepted and $\mathrm{H}_{\mathrm{a}}$ rejected. Based on these results, it shows that partially has a significant effect Total Asset Turnover(TATO) against Return On Equity (ROE) in transportation companies listed on the Indonesia Stock Exchange for the period 2015-2019.

Total Asset Turnover shows the level of efficiency in the use of overall company assets in companyactivities. Total Asset Turnover is important for creditors and company owners, but it will be even more important for company management, because this will show the efficiency of the use of all activities within the company. The higher the level of sales in the future so that changes in profits are higher. The higher the sales, the higher the sales. also the level of efficiency and effectiveness of the company in carrying out its operations. The higher total asset turnoverthe higher the change in profitThe results of this study are in line with the results of research conducted by (Jufrizen\& Sari2019) and (Jufrizen, 2015) which states that Total Asset Turnover significant effect on Return On Equity. But this study is not in line with the research results (Jessica etal., 2019) which states that Total Asset Turnover has no significant effect on Return On Equity.

Therefore the results of the research conducted by the research as well as the theory as well as the income presented above are about influence Total Asset Turnover to Return On Equity. So the writer can conclude that there isan agreement between the results of the research with the theory. So the writer can conclude that the Total Asset Turnover to Return On Equity is a significant effect on Transportation sector listed on the Indonesia Stock Exchange forthe period 20152019.

\section{Influence Current Ratio (CR) Debt To Equity Ratio (DER) and Total Assets Turnover ( TATO) Against Return OnEquity (ROE)}

Based on the F test which tests simultaneously whether the two independent variables are the dependent variable, namely Current Ratio (CR), Total Asset Turnover (TATO) and Debt To Equity Ratio (DER) has a simultaneously significant influence relationship Return On Equity (ROE), then we get fcountamounting to 10,431 with a significant 0,000 . Medium $\mathrm{f}_{\text {table }} 2.91$ significantly. 


\section{International Journal of Business Economics (IJBE)}

Vol, 2 Issue 2, pp 99-112, March - August 2021

http:/ /jurnal.umsu.ac.id/index.php/ijbe

eISSN 2686-472X

Thus $\mathrm{H}_{\mathrm{o}}$ rejected and $\mathrm{H}_{\mathrm{a}}$ be accepted. So it can be concluded that Current Ratio (CR), DebtToEquity Ratio (DER) and Total Asset Turnover (TATO) and together there is a significant influence on Return On Equity (ROE), because $f_{\text {count }}>\mathrm{ft}_{\text {able }}$ ( $10,431>2.91)$ and the significance value is $0.000<0.05$. Show that there is an influence of the independent variable (Current Ratio, Debt to Equity Ratio, Total Assets Turn Over) simultaneously is significant for Return On Assets. Then it can be concluded that simultaneously Current Ratio, Debt to Equity Ratio, Total Assets Turn Over effect on Retturn On Equtiy in transportation sector companies listed on the Indonesia Stock Exchange for the 2015-2019 period

\section{CONCLUSION}

Based on the results of the research and discussion that has been stated previously, conclusions canbe drawn from research on influence Current Ratio ( CR), Debt To Equity Ratio ( DER) against Return On Equity ( ROE) in Transportation Sector Companies listed on the Indonesia Stock Exchange for the 2015-2019 period with asample of 7 companies are as follows: The results of the research partially prove that Current Ratio effect but not significant to Return On Equity in Transportation Sector Companies listed on the Indonesia Stock Exchange for the period 2015-2019. The research results partially prove thatDebt To Equity Ratio effect but not significant to Return On Equity onTransportation sector companies listed on the Indonesia Stock Exchange for the period 2015-2019. The research results partially prove that Total Asset Turnover significant effecttoReturn On Equity in Transportation Sector Companies listed on the Indonesia Stock Exchange for the period 2015-2019. The results simultaneously prove that Current Ratio, Debt To Equity Ratio and Total Asset Turnover significant effect on Return On Equity in Automotive Sector Companies listed on the Indonesia Stock Exchange for the period 2015-2019.

\section{REFERENCES}

Alpi, M. F. (2018). Pengaruh Debt to Equity Ratio, Inventory Turnover dan Current Ratio Terhadap Return ON Equity Pada Perusahaan Sektor Farmasi Yang Terdaftar Di Bursa Efek Indonesia. In Prosiding The National Conference on Management and Business (NCMAB) (pp. 158-175).

Argananta, R. J., \& Hidayat, I. (2017). Analisis Pengaruh CR, DER dan TATO Terhadap ROE pada PT. Mustika Ratu Tbk. Jurnal Ilmu Dan Riset Manajemen, 6(10), 1-19.

Destari, A. Y., \& Hendratno. (2019). Analisis Pengaruh Debt to Equity Ratio, Current Ratio, Total Assets Turnover dan Size Terhadap Return On Equity. Jasa (Jurnal Akuntansi, Audit Dan Sistem Informasi Akuntasi), 3(1), 95-107.

Ekananda, M. (2019). Manajemen Investasi. jakarta: Penerbit Erlangga.

Fahmi. (2017a). Analisis Laporan Keuangan. Bandung: CV. Alfabeta.

Fahmi, I. (2017b). Analisis Laporan Keuangan. Bandung: Alfabeta.

Hasibuan, J. S. (2018). Pengaruh Current Ratio dan Debt to Equity Ratio Terhadap Return On Equity Pada Perum Perumnas Regional I Medan. Prospek Dan Tantangan Pengelolaan Keuangan Desa, 1(1), 1-15.

Jessica, J., Lilia, W., Leonardy, C., Kartika, M., \& Panggabean, N. (2020). Pengaruh ITO, CR, DER, TATO dan WCTO Terhadap ROE Pada Perusahaan Aneka Industri Terdaftar di BEI. Berkala Akuntansi Dan Keuangan Indonesia, 4(2), 43-56. https://doi.org/10.20473/baki.v4i2.16792 


\section{International Journal of Business Economics (IJBE)}

Vol, 2 Issue 2, pp 99-112, March - August 2021

http://jurnal.umsu.ac.id/index.php/ijbe

eISSN 2686-472X

Juandi, B. A., Djamereng, A., \& Budiandriani. (2019). Pengaruh Current Ratio , Debt to Equity Ratio dan Total Asset Turnover terhadap Return on Equity pada PT. Hutama Karya. Paradoks: Jurnal Ilmu Ekonomi, 2(4), 1-9.

Jufrizen, J. (2015). Pengaruh Inventory Turn Over Dan Fixed Asset Turn Over terhadap Return on Equity pada Perusahaan Farmasi yang Terdaftar di BEI Tahun 2007-2013. Jurnal Kajian Manajemen Bisnis, 4(1), 110-128. https://doi.org/10.2403/jkmb.618100

Jufrizen, J., \& Sari, M. (2019). Pengaruh Current Ratio, Debt to Equity Ratio dan Firm Size terhadap Return on Equity. Jurnal Riset Akuntansi : Aksioma, 18(1), 156-191. https://doi.org/10.29303/aksioma.v18i1.58

Juliandi, A., \& Irfan. (2013). Metode Penelitian Kuantitatif (pertama). Medan: Citapustaka Media Perintis.

Kasmir. (2012). Analisis Laporan Keuangan. Jakarta: PT. Raja Grafindo Persada.

Pratomo, A. J. (2017). Pengaruh Debt to Equity Ratio (DER) Dan Current Ratio (CR) Terhadap Return on Equity (ROE). Studi Empiris Pada Perusahaan Sub Sektor Kabel Yang Terdaftar di Bursa Efek Indonesia Pada Tahun 2013-2016. Jurnal Manajemen Dan Bisnis, 5(4), 942-956.

Prihadi, T. (2019). Analisis Laporan Keuangan Konsep dan Aplikasi. Jakarta: Pt. Gramedia Pustaka Utama.

Putra, H. S. (2020). Pengaruh Current Ratio dan Total Assets Turnover Terhadap Price to Book Value Dengan Dimediasi Oleh Return On Equity pada Perusahaan Sub Sektor Farmasi Yang Terdaftar Di Bursa Efek Indonesia. Maneggio: Jurnal Ilmiah Magister Manajemen, 3(1), 92-106. https://doi.org/10.30596/maneggio.v3i1.4856

Sipahutar, R. P., \& Gultom, D. K. (2017). Pengaruh Debt To Equity Ratio Dan Longterm Debt To Equity Ratio Terhadap Return On Equity Dengan Ukuran Perusahaan Sebagai Variabel Moderating Di Bursa Efek Indonesia. Jurnal Riset Finansial Bisnis, 1(2), 137-146. https://doi.org/10.5281/zenodo.1098493

Sudana, I. M. (2011). Manajemen Keuangan Perusahaan. (Novietha I. Sallama, Ed.). Surabaya: PT. Gelora Aksara Pratama.

Sudana, I. M. (2015). Manajemen Keuangan Perusahaan Teori dan Praktik (Edisi 2). Jakarta: Erlangga.

Sugiyono. (2017). Metode Penelitian Pendidikan (Dua Belas). Bandung: Alfabeta.

Sujarweni, W. (2015). Statistik Untuk Bisnis Ekonomi (Pertama). Yogyakarta: Pustaka Baru Pers.

Wahyuni, S. F. (2017). Peran Kepemilikan Institusional Dalam Memoderasi Pengaruh Current Ratio, Debt To Equity Ratio Total Asset Turnover Dan Inventory Turnover Terhadap Return On Equity Di Bursa Efek Indonesia. Jurnal Riset Finansial Bisnis, 1(2), 147-158.

Yusnandar, W. (2019). Pengaruh Current Ratio, Return On Asset, Asset Structure Dan Total Asset Turnover Terhadap Debt To Equity Ratio Pada Perusahaan Perkebunan Yang Terdaftar Di Bursa Efek Indonesia. Jurnal Krisna: Kumpulan Riset Akuntansi, 11(1), 71-80. 